\title{
A critical consideration of ethical foundations for the accounting profession
}

\begin{abstract}
Authors:
Pieter Buys ${ }^{1}$

Susan Visser ${ }^{1}$

Merwe Oberholzer ${ }^{1}$

Affiliations:

${ }^{1}$ School of Accounting

Sciences, North-West

University, South Africa

Correspondence to:

Pieter Buys

Email:

pieter.buys@nwu.ac.za

Postal address:

Private Bag X6001,

Potchefstroom 2520,

South Africa

Dates:

Received: 27 June 2012

Accepted: 29 Aug. 2012

Published: 13 Dec. 2012

How to cite this article:

Buys, P., Visser, S. \&

Oberholzer, M., 2012, 'A

critical consideration of

ethical foundations for the accounting profession',

Koers - Bulletin for Christian Scholarship 77(2), Art. \#45,

7 pages. http://dx.doi.org/

10.4102/koers.v77i2.45
\end{abstract}

(C) 2012. The Authors.

Licensee: AOSIS

OpenJournals. This work

is licensed under the

Creative Commons

Attribution License.
When considering some of the key reasons for the desperate state of the current global economic environment, it is difficult to deny accounting's role therein. Although accounting institutes require adherence to codes of conduct, the question remains as to what happened to the stewardship function of the accounting profession. This article has critically reflected on the question, 'What constitutes an ethical accounting profession'? The key principles within many institutes' codes of conduct, such as competency, integrity, objectivity and confidentiality, have been considered against the background of utilitarianism, formalism and virtue ethics as foundational ethical theories. This article has concluded that although these principles aim to provide a framework for ethical accounting conduct, individual subjectivity on the part of the accountant will play a role in how these ethical principles become ethical practices.

'n Kritiese oorweging van die etiese grondslae vir die rekeningkundige professie. Wanneer sommige van die vernaamste redes vir die desperate toestand van die huidige globale ekonomiese omgewing oorweeg word, is dit moeilik om rekeningkunde se rol daarin te ontken. Hoewel rekeningkundige instellings die nakoming van gedragskodes vereis, ontstaan die vraag na wat van die rekeningkundige professie se rentmeesterskapfunksie geword het? In hierdie artikel is krities gereflekteer op die vraag, 'Wat behels 'n etiese rekeningkundige professie?'. Die belangrikste beginsels in vele instellings se gedragskodes, soos bevoegdheid, integriteit, objektiwiteit en vertroulikheid, is beoordeel teen die agtergrond van utilitarisme, formalisme en deugde-etiek as fundamentele etiese teorieë. Hierdie artikel het tot die gevolgtrekking gekom dat, alhoewl sodanige beginsels daarna streef om ' $n$ raamwerk te voorsien vir etiese rekeningkundige gedrag, individuele subjektiwiteit aan die kant van die rekenmeester 'n deurslaggewende rol sal speel in hoe hierdie etiese beginsels omgeskakel word in etiese 'praktyke'.

\section{Background}

In Roman mythology, Janus, the god of gates and doorways, is often depicted as having two faces, one forward facing and the other rearward facing (Eadie 2007:636; Teske 2005:290). This depiction can be applied to the ethical issues facing the professional accountant, for example, the simultaneous consideration of both future and historic events, or the many opposing needs and requirements of the various stakeholders in an organisation. As a discipline, accounting wears many hats. On the one hand, there is the historical aspect in which business transactions are recorded in the accounting records and which are then reported to the various stakeholders. This is typically the domain of financial accounting and is very much backward looking. On the other hand, there is a forward-looking component that aims to foresee the future and as such makes plans for that future based on available financial information and corporate performances. This is typically the domain of managerial accounting. Between these backward- and forward-looking functions, there are also many subjective grey areas such as cost allocations, asset valuations and information interpretation.

The accountant is thus often in the unique position of being able to influence decision-making by presenting information in such a way that it is able to support different alternatives or viewpoints. It is perhaps prudent to mention the role of the auditor in this context. As a related accountancy function, the purpose of the audit process includes to investigate and review, primarily but not only, the accounting records and transactions of an organisation. Within this function there are two broad audit functions. Firstly, the purpose of the (independent) external audit function revolves around the reasonableness of the financial information and the compliance to applicable rules and regulations. The audience of this audit report is typically the external stakeholders. The internal audit function in contrast often involves very detailed and targeted investigations into specific areas of the organisation to ensure regulatory compliance and company policies. The audience of this report is then also typically internal to the organisation. Although integrally part of the broader accounting function, the article's focus per se is not on the audit function, but rather on the accounting function and the ethical aspects around it. 
In the light of the technical focus of accounting education, training and practice, ethics is often not an area that stands out as part of the core technical skills of an accountant. However, considering the world's current financial woes and its link to the sub-prime crisis (Richards 2008), recent corporate failures such as Enron in the United States of America (USA) and Parmalat in Italy (Buys 2008:499), or even Fidentia in South Africa (Van Romburgh 2008:1), and accounting's role therein, one can not but wonder what happened to the noble stewardship role of the accounting profession. The reader must be mindful that blame for cases such as those mentioned should not be placed at the feet of accounting, but is rather caused by the manipulation and selective disclosures of accounting information.

We do not infer that the profession is at fault, but rather that the (mis-)use of accounting skills has provided the vehicle in which to perpetrate the actions resulting in these cases. It seems as if Dante's deadly sin of avarice (or greed) is running amok in modern society and accounting is providing the vehicle to perpetrate this sin. Avarice, which turns people away from God by creating a preoccupation with the acquisition of material possessions, is commonly defined as the excessive love of money (Webster's Dictionary and Thesaurus 2006:26; Hole \& Hawker 2004:32) and is often manifested in miserliness and unethical business practices. Many accountants may not consciously link their actions to ethical norms and in the case of a dispute they will probably attempt to resolve such disputes by some form of legal action. Ethics, however, is considered a person's moral duty to society and a broader concept than only that which is required by law (Gellerman 2003:51; Rossouw 2002:412). Notwithstanding differing interpretations of ethics, they are all based on the same principle: that each person in the group or society carries some responsibility for the well-being of others in the group.

Although ethics is often considered as having evolved out of the philosophy of human behaviour, Nash (2003:22) states that business professionals and philosophers have different approaches to ethical issues. Given the realities of the modern business environment and its constant claim on the available resources, intangible and paradoxical ethical philosophies may often not be considered part of the decision-making framework, for example, when manipulating company earnings under pressure from shareholders by 'creative accounting' practices (Vranceanu 2005:100).

\section{Problem statement and method}

Following from the above, this article aims to reflect on a crucial concept in the practice of accounting, namely ethical accounting behaviour. Set against the backdrop of the tumultuous state of the current global financial world and the many efforts to make some sense and clarity of it, the primary question under consideration in this article can be formulated as follows, 'What are some of the key ethical considerations in accounting and to what extent does it impact the accounting profession'?

This article is based on a literature study research method and utilises a three-step approach in critically reflecting on ethical aspects in the accounting profession. To set the background for the discussion, the article firstly highlights utilitarianism, formalism and virtue ethics as key streams of ethical theory. Secondly, it considers fundamental accounting conduct aspects in ensuring ethical accounting behaviour. Finally, it reflects on the effectiveness of these fundamental principles in ensuring ethical accounting behaviour.

\section{Ethical theory}

Business ethics, according to the Institute of Directors in Southern Africa (IDSA) (2009:51), refers to the ethical values that determine the interaction between a company and its stakeholders. Sellers and Arrigo (2009:451-461) as well as Shao, Aquino and Freeman (2008:530) identified the following two discernable and basic ethical approaches in the literature, namely, (1) formalism and (2) consequentialism. Kraut (2012) and Hursthouse (2012), however, identify virtue ethics as a further approach to ethical philosophy and as one of the three major approaches in normative ethics, the other two being deontology (or formalism) and consequentialism. In respect of the latter approach, it assumes only one basic duty, namely, to do whatever has the best consequences, and includes approaches such as ethical egoism, contractualism and utilitarianism. According to Regis (1980), ethical egoism may be defined as a prescriptive doctrine that all persons ought to act from their own self-interest, which as a philosophical interest has received prominence second only to utilitarianism. Contractualism as a method of moral reasoning departs from a viewpoint that morality is based on agreement (or social contract) and that decisions are justifiable only to the extent to which they are coherent between moral agents (Ashford \& Mulgan 2009). Finally, the essence of utilitarianism is found in striving to attain the benefit for every person affected by a particular situation (Tidmarsh 2009:1144).

Within the context of the accounting profession, three of the above approaches may be specifically applicable. On the one hand, the profession is often seen as having a stewardship role and as such should strive towards the safeguarding of the interests of all stakeholders (i.e. a utilitarian perspective). There are also the many laws and regulations that are applicable in accounting. As such, professional accountants operate very much in a formalistic environment. Finally, accounting is practised by human beings each of whom has a unique personality, character traits, virtues and vices. Thus, for the purposes of this article the concepts of utilitarianism, formalism and virtue ethics are briefly considered.

\section{Utilitarianism}

Utilitarianism is, according to Sellers and Arrigo (2009:452), a unique form of consequentialism in the sense of it being altruistic and fostering the principle of utility. Livingstone (2008:730) defines the term utility as the state of being useful, to which Hole and Hawker (2004:614) also add the state of being profitable. Leading on from utility, utilitarianism is therefore the belief that the overall guiding principle of behaviour should aim to achieve the greatest happiness for the majority (Sellers \& Arrigo 2009:452; Hole \& Hawker 
2004:614). Although Tidmarsh (2009:1144-1145) considers utilitarianism (alongside ethical egoism) as a controversial ethical theory, he is in general agreement by stating that utilitarianism is a consequentialist theory that argues that people should act in such a manner that the utility for everybody concerned is maximised.

Based upon the aforementioned, it seems as if the concept of utilitarianism can therefore be defined as the ethical theory that finds the basis of moral distinctions in the utility of actions, which must result in the ability to find happiness for the majority. However, specifically within an accounting context, there are certain drawbacks to this approach, including the possibility of the exploitation of minority stakeholders' interests in favour of those of the majority stakeholders.

\section{Formalism}

Whereas utilitarianism is concerned with consequences and the benefit for the majority, formalism is defined as an excessive concern with rules and outward form (Hole \& Hawker 2004:221). It is also seen as a strict observance of form or conventional usage (Webster's Dictionary and Thesaurus 2006:149). The concept of formalism can therefore be seen as the strict observance of form or the adherence to rules and regulations. Jialiang (2008:56), however, provides a slightly different perspective by stating that the actual operation of such rules and laws is often based on the logic of pragmatism under the guise of formalism. When considering the foregoing within an accounting context, the promulgated accounting regulations, standards and principles would therefore only be considered ethical if all stakeholders, without qualification, would interpret and apply such regulations, standards and principles in a similar fashion, given the specifics of a particular scenario.

A key advantage of formalism is the collective logic on which it bases the guidelines for acceptable behaviour. Unfortunately, rules can often become very cumbersome and complex. Further disadvantages may also include its dogmatic perspective, in which over reliance may be placed on a specific rule or when a specific rule is used as a screen to hide behind.

\section{Virtue ethics}

In contrast to utilitarianism, which considers consequences, and formalism, which emphasises rules and duties, virtue ethics emphasise the moral character of the individual (Hursthouse 2012). This approach considers virtues to be central to a well-lived life and regards the ethical virtues, such as justice, courage and temperance as complex rational, emotional and social skills (Kraut 2012). From this encompassing concept, both Kraut (2012) and Hursthouse (2012) derive three more specific concepts, namely (1) arête [excellence or virtue], which is a character trait or disposition that is well entrenched in its possessor, (2) phronesis [practical or moral wisdom], which cannot be acquired solely by learning rules, but acquired through deliberate practice, that is, deliberative and (3) eudaimoni [happiness or flourishing].
Thus, in the context of this article, this classification of ethics argues that the accountant's identity drives his or her behaviour, and that character often trumps rules and/ or the penalties or benefits of consequences. According to Hursthouse (2012), the complaint is that virtue ethics does not produce codifiable principles, and as such it is unable to provide guidance in actions. In a Christian context, however, we do have such codifiable principles in the example of Christ and the guidance of the Bible.

\section{Ethical conduct and the accountant}

The Code of Governance Principles for South Africa 2009 (known as King III) lists integrity, respect, truthfulness, responsibility, accountability, fairness, transparency and loyalty as examples of ethical values (IDSA 2009:52). According to Ernst \& Young (2009:ii), King III attempts to move towards a more principle-based approach in corporate governance. Ethical behaviour, within the context of corporate social responsibility, becomes the responsibility of The Board of Directors (hereafter 'the Board') (Serratta, Bendixen \& Sutherland 2009). The Board should therefore ensure that management cultivates a culture of ethical conduct through (1) the creation of an ethics risk profile and the establishment of a code of conduct, (2) through the integration of ethics into all company practices, procedures, policies and conduct and (3) through the assessment, monitoring, reporting and disclosure of the company's ethics performance (Ernst \& Young 2009:1; IDSA 2009:20-21).

More specific to the accounting function, the accounting profession's stewardship role makes it crucial to maintain high standards of ethical conduct. A code of ethical conduct is so important that it is often set as a prerequisite for the recognition of accounting as a professional vocation. As mentioned earlier, there are two basic professional streams in accounting, namely financial accounting (which can be seen as considering historic events) and management accounting (which can be seen as considering future events). In this article's consideration of ethical considerations in the accounting profession, the financial accounting discipline is represented by:

- the American Institute of Certified Public Accountants' (AICPA) Code of Professional Conduct

- the Institute of Chartered Accountants in England and Wales' (ICAEW) Code of Ethics

- the South African Institute of Chartered Accountants' (SAICA), Code of Professional Conduct.

From the perspective of management accounting, the discipline is represented by:

- the US-based Institute of Management Accountants' (IMA) Statement on Ethical Professional Practice

- the UK-based Chartered Institute of Management Accountants' (CIMA) Code of Ethics for Professional Accountants.

From the above institutes' codes of conduct, four fundamental principles are identified as typical in promoting the objectives of an 'ethical' accounting profession. These are professional competency, integrity, objectivity and confidentiality. More consideration is now given to each concept. 


\section{Professional competency}

In order to get some clarity on this concept, one needs to consider the literal meaning of the phrase 'professional competency'. According to Livingstone (2008:519), and Hole and Hawker (2004:440), the term 'professional' refers to (1) being competent or skilful and (2) belonging to a profession. The Webster's Dictionary and Thesaurus (2006:296) takes the definition somewhat further by stating that the term professional means to conform to the technical or ethical standards of a profession. As the supplemental term to this concept, 'competent' (including 'competence') is defined by Livingstone (2008:131) and Hole and Hawker (2004:108) as having the necessary skill or knowledge, whilst the Webster's Dictionary and Thesaurus (2006:77) refers to the word 'competency' as sufficiency or capability.

In respect of the accounting institutes' perceptions, the CIMA (2009:7), the ICAEW (2009:165-166), the AICPA (2008:ET Section 56, Article V) and the SAICA (2006:5) state that the principles of professional competence and due care impose on accountants the requirement to maintain their professional knowledge and skill at acceptable levels and to act in accordance with the applicable technical skills and professional standards. The IMA (2005:1) is in agreement with this statement, but also adds the requirement for management accountants to provide decision support information that is accurate, clear, concise and timely, as well as to communicate any limitations or constraints that might hinder the accountant in successfully completing an assignment.

Within the broader context of the accounting profession, the concept of professional competency is therefore taken as referring to the accountant's ability to obtain and maintain acceptable levels of accounting-related capabilities. This can be achieved by:

- continuously developing their personal competencies and knowledge

- executing their responsibilities in line with relevant laws and regulations

- issuing reports and recommendations only once they have personally completed the assignment.

\section{Integrity}

According to Livingstone (2008:355), the term 'integrity' means honesty, and provides synonyms thereof as rectitude, virtue, probity, principle, morality, honour and decency. Hole and Hawker (2004:292) provide a more specific definition by stating that integrity is a quality of being honest and fair.

Within a more accounting-specific context, integrity is an element of character fundamental to professional recognition (AICPA 2008. ET Section 54, Article III). The principle of integrity also imposes an obligation on the accountant to be straightforward and honest in all professional relationships (CIMA 2009:6; ICAEW 2009:165; SAICA 2006:5; IMA 2005:1/2), which then also implies fair dealings and truthfulness and even abstaining from accepting engagements that might be seen as discrediting the profession.
Thus, considering the above, the concept of integrity within an accounting context may be defined as honesty and sincerity in the daily application and practice of accounting skills. An accountant with integrity will therefore not be dishonest and would not get involved in the falsification of information. The characteristics of integrity become a reality in the concepts of full disclosure of relevant financial information. The accountant with integrity will therefore:

- avoid situations of possible conflict and inform all stakeholders should a conflict situation become reality

- not undertake appointments that may make it difficult to maintain integrity in an ethical manner

- not accept gifts or favours that may create the impression of influencing their responsibilities

- refrain from subverting the attainment of the organisation's legitimate and ethical objectives.

\section{Objectivity}

Both Livingstone (2008:450) and Hole and Hawker (2004:379) define the term 'objectivity' as (1) not being influenced by personal feelings or opinions or (2) even having an actual existence outside the mind. The Webster's Dictionary and Thesaurus (2006:253) confirms the foregoing by defining objectivity as something, or someone, which is detached or impartial.

The principle of objectivity in the accounting institutes' perspective imposes the obligation not to compromise professional judgement because of bias, conflict of interest or the undue influence of others (CIMA 2009:7; IACEW 2009:160; SAICA 2006:5). The IMA (2005:2) considers objectivity as part of their overall credibility principle, which requires, inter alia, the fair and objective communication of all information that could reasonably be expected to influence the intended user's understanding of the reports, analyses or recommendations. The AICPA (2008:ET Section 55, Article IV) further states that independence precludes relationships that may even only appear to impair a member's objectivity in rendering attestation services.

The concept of objectivity can be defined as when an accountant is actually independent and unbiased, as well as being perceived as independent and unbiased, when it comes to business facts and the situation at hand, whether from a personal perspective or from being influenced by others. When facing ethical questions, it is necessary for the accountant to consider other stakeholders' feelings and motives. The accountant therefore has the responsibility to:

- communicate all information honestly and objectively

- disclose all relevant information that can be expected to influence the end-user's decisions.

Although a management accountant is typically employed by a company and is not independent in the same sense as an external accountant and auditor, the management accountant should also be able to distance himself or herself from a conflict situation in order to consider all the relevant aspects objectively. 


\section{Confidentiality}

The term 'confidential' means that something has to be kept secret or classified and off-the-record (Livingstone 2008:137; Hole \& Hawker 2004:172). The Webster's Dictionary and Thesaurus (2006:79) states that when something is confidential it has been entrusted with secrecy.

The principle of confidentiality imposes an obligation on accountants to refrain from disclosing any confidential information obtained as a result of professional relationships, or to use such information for personal or another third party's benefit (CIMA 2009:8; ICAEW 2009: 166,167; SAICA 2006:5). The IMA (2005:1) adds the further requirement of informing all relevant parties regarding the appropriate use of confidential information.

Thus, confidentiality within an accounting context means that the accountant will not use information obtained during the fulfilment of any professional duties for personal gain and should therefore not:

- disclose confidential information obtained during the course of professional duties, except when required by law

- fail to inform subordinates of the confidential nature of the information and ensure confidentiality is maintained

- use, or pretend to use, any confidential information to gain some unfair or unethical benefit.

Considering that the confidentiality principle binds the accountant to not disclose client or employer information, cases of ethical conflict found within the client or employer environment should initially be handled based on such a client's corporate procedures to resolve the conflict (ICAEW 2009:166,167; CIMA 2009:8). If this should prove to be insufficient, the institutes' guidelines suggest seeking counselling and advice on a confidential basis with an independent advisor or the applicable professional accounting institute to obtain an understanding of the possible courses of action. However, this may be seen as exceptions to the confidentiality rule. The accountant should therefore use proper judgement even when approaching an independent person.

\section{Discussion}

When considering the question of what an ethical accounting profession entails, a key aspect that comes to mind is the concept of professional behaviour and what such behaviour constitutes. Within the context of the accounting profession, it is the manner in which an accountant, as a dedicated professional, would conduct and express himself or herself in his or her chosen vocation. In the above sections, four principles that should guide an ethically-focused accountant in his or her behaviour have been identified as those that key accounting institutes consider as fundamental to their codes of ethical conduct. However, seen in the light of the recent global corporate failures and scandals, one cannot but wonder whether these so-called codes of ethical conduct are sufficient to prevent such scandals. Consequently, a reflection on these principles might be in order.
Firstly, in terms of professional competence, all five of the accounting institutes considered in this article requires their members to pass very stringent and multiple professional exams covering core accounting-related subjects (NASBA 2010; ICAEW 2010a; SAICA 2009; IMA 2009a; CIMA 2009). Furthermore, these institutes also require their members to comply with periodic continuous professional educational requirements in some form or another (AICPA 2009; ICAEW 2010b; SAICA 2008; IMA 2009b; CIMA 2010). It is also likely that most other accounting institutes in the world would have similar examinations and continuous professional educational requirements in order to obtain and maintain membership. It is thus unlikely that incompetence on the part of the accounting professional is a key contributing factor to the current woeful global economic environment.

Secondly, integrity is perhaps the only principle of the identified four fundamental principles that reflects directly on the nature of the human being, which within this article's context is that of the accounting professional. It is, perhaps, also the closest link to virtue ethics as a reflection on personal character. It speaks of the essence of the person and it may be quite likely that integrity (or rather a lack thereof) is a major contributing factor in perpetrating fraudulent activities that might result in the scale of corporate failures referred to earlier. The constantly increasing secularisation of society may be a key factor in limiting the influences of family, church and religion, and even education, in shaping moral individuals (Andrews 2003:69-70). This modern secular society's focus on immediate self-gratification should be of concern to all of humanity. In such individualistic-centred cultures, everyone is expected to look after himself or herself and his or her immediate family (Hofstede 1983:77). There is therefore a definite risk that the stewardship principle, including the responsible use of natural and other resources, may be diminished. Earlier it has been highlighted that utilitarianism aims to seek the greatest happiness for the majority, yet humankind's natural inbred avarice merely leads to ophelimity (or pure economic satisfaction) and self-gratification.

Thirdly, the ability of an individual to be truly objective under all circumstances may be a further point of concern. According to Andrews (2003:73-75), human character becomes decisive in instances where there are no absolute choices. Objectivity was seen as the ability to be unbiased and not influenced by personal feelings, which might be easier to comply with in a formalistic environment clearly governed by rules and regulations. However, when the stakes are high and an overload of accounting rules might make it difficult to distinguish between what is right and wrong, the accountant's objectivity might come under pressure from two sides. Firstly, personal circumstances (at home or at work) might blur the distinction between what is right (objectivity) and what is wrong (subjectivity). Secondly, superiors might also exert pressure on junior staff members, which might also blur the line between objectivity and subjectivity. In both these instances, the accountant's ability to apply the objectivity principle comes down to the individual's integrity. 
Finally, when considering the Webster's Dictionary and Thesaurus' (2006:79) definition of confidentiality, this final fundamental principle can be linked to secrecy. At first glance, this might seem to be a good thing and may not be seen as being a contributing factor to the current sorry state of affairs as far as the financial world is concerned. However, transparency, which stands in direct contrast to secrecy, is, according to the IDSA (2009:52), also an example of an ethical value. Within the context of ethical accounting behaviour, secrecy should therefore not be seen in the same light as confidentiality. It can be argued that secrecy implies the hiding of facts from becoming known and as such has a sinister motive behind it. Confidentiality, however, does not have sinister motives, but rather aims to protect the competitive information of an organisation in order to ensure that such an organisation remains sustainable.

Furthermore, confidentiality also implies not using confidential information for personal gain. The question is, however, whether this is actually achievable? As a skilled professional in the service of a business organisation, the accountant will inevitably at some stage gain access to sensitive or inside information that might, for example, be used for beneficial investment opportunities. In such circumstances, it will take a person with strong character to withstand the temptation to breach the confidentiality principle. An accountant might justify unethical actions by thinking 'nobody will get hurt' or 'this is only a small financial gain'. However, greed is greed and unethical behaviour remains unethical and there are no degrees of greed or unethical behaviour. Again, the ability to maintain this fundamental principle comes down to the individual's integrity.

Bringing all the above together, it is unlikely that professional incompetence should be a major area of concern in large-scale ethical (and corporate) failures. Considering the education and training requirements of the professional accountant, combined with the continuous professional development requirements as mentioned earlier, most professional accountants should be competent in practising their vocation. The principles of objectivity and confidentiality, however, were seen as potential contributing factors to failures in the fundamental principle of integrity. Considering the above, it may be argued that failures in human integrity are very often to blame in corporate and financial scandals.

According to the IDSA (2009:52), ethical values translate into behavioural directives (or standards and guidelines) as well as behavioural commitments (or principles). Ethical accounting conduct, which includes the professional accounting institutes' codes of conduct, can therefore be seen as embracing both extremes in ethical theory, as discussed earlier. On the one hand, there is the formalistic aspect (or the behavioural directives) that is embodied in the specific rules of the conduct codes. The accountant should be cognisant of the requirements of these codes and adhere to them as if such codes have 'legal' stature. On the other hand, there is the utilitarianism aspect (or the behavioural commitments) that is embodied in the spirit of the conduct codes. When referring to the spirit of the conduct codes, the accountant should not be so narrow-minded as to always follow the letter of the law', especially in attempts to conceal or find loop-holes to justify unethical behaviour.

\section{Conclusion and recommendation}

The perceptions of top management's ethical approach are important in setting an example for what is acceptable behaviour (Ernst \& Young 2009:9) and the organisational leadership should be based on an ethical foundation (Ernst \& Young 2009:1; IDSA 2009:19). Notwithstanding this, the question remains as to whether adding more rules, regulations and governance codes to existing codes will bring additional sureties in enhancing ethical behaviour. The answer to this question is that in all probability it will not. One could become fatalistic and merely throw one's arms in the air and state that all is lost. There are just too many greedy people in the world with no ethical morals and the desire for self-enrichment is just too great. However, the bigger failure would be not to try and curb the tide of growing greed and unethical behaviour, especially in the accounting profession. The accounting institutes' codes of professional conduct, such as those discussed earlier, are a good starting point, but it should not merely remain there.

Professional behaviour requires that the accountant refrains from any actions that may place the profession in a bad light (CIMA 2009:9; ICAEW 2009:170; SAICA 2006:6). However, professional behaviour is more than just about the image of the accounting profession. It is also about the image of the accountant regarding his or her employer and/or client. Based on the above discussion, principles such as fairness, responsibility and transparency (IDSA 2009:9), as well as balance and consideration towards others, are crucial to ethical accounting behaviour. Although an accounting institute's ethical code of conduct aims to meet these principles, one should always remember that no code will address all possible ethical conflicts that an accountant might encounter. The ultimate aim of an institute's codes of conduct is to provide a framework for ethical behaviour and it is important for an accountant to operate within this framework. Although the accountant's interpretation of this framework is often formed through personal experience and training, there are certain principles that the 'ethical accountant' should strive for:

- Avoid small ethical failures. Although it may initially seem unimportant, there is a possibility of exploitation later on by unscrupulous individuals.

- Focus on the long-term reputation. Accountants should try and ignore short-term pressures and focus on his or her long-term reputation.

- Be prepared to face personal consequences. The ethical accountant may face two choices: to let go of ethical standards and obtain certain benefits or be ignored when promotional opportunities arise. 
Finally, should the ethical problems not be satisfactorily resolved, accountants have no other option but to resign their position within an organisation or appointment from a client.

In conclusion, how does all this impact on the Christian accountant? From a Christian perspective, the stewardship role is firstly towards God (through Jesus Christ). Therefore, in order to practice ethical accounting, the Christian accountant's identity should always drive his or her actions (i.e. the virtue ethical aspects). Secondly, in those cases where there are specific rules and regulations to be complied with, they should be obeyed (i.e. the formalistic aspects). Thirdly, in matters that are of a more neutral matter, the Christian accountant should (in the mindset of virtuosity) act in a Christ-guided manner towards the relevant stakeholders (i.e. the utilitarianism aspects).

\section{Acknowledgements Competing interests}

The authors declare that they have no financial or personal relationship(s) which may have inappropriately influenced them in writing this article.

\section{Authors' contributions}

The article was researched and written by P.B. (North-West University) as part of a PhD research project. The secondary authors, S.V. (North-West University) and M.O. (North-West University) fulfilled 'reviewer' functions as the PhD study's promoter and assistant promoter respectively.

\section{References}

The American Institute of Certified Public Accountants (AICPA), 2009, Continuous Professional Education, viewed 18 December 2009, from http://www.aicpa.org/ CPEAndConferences/CPERequirements/Pages/CPERequirements.aspx

The American Institute of Certified Public Accountants (AICPA), 2008, Code of Professional Conduct, viewed 24 July 2009, from http://www.aicpa.org/About/ code/index.html

Andrews, K.R., 2003, 'Ethics in practice', in Harvard Business School Press \& J.L. Badaracco (eds.), Harvard Business Review on Corporate Ethics, pp. 69-70, Harvard Business School Publications, Boston.

Ashford, E. \& Mulgan, T., 2009, 'Contractualism', The Stanford Encyclopedia of Philosophy, Winter, viewed 15 March 2012, from http://plato.stanford.edu/ archives/win2009/entries/contractualism

Buys, P.W., 2008, 'In pursuit of a foundational accountancy philosophy', Koers 73(3), pp. 489-509.

Chartered Institute of Management Accountants (CIMA), 2010, CIMA professiona development, viewed 19 April 2010 from http://www.cimaglobal.com/ Members/CIMA-Professional-Development/

Chartered Institute of Management Accountants (CIMA), 2009, The CIMA syllabus, viewed 18 December 2009, from http://www.weball.org/CIMA_syllabus.htm

Eadie, P., 2007, 'Poverty, security and the Janus-faced state', British Journal of Politics and international relations 9(4), pp. 636-653. http://dx.doi.org/10.1111/j.1467 856X.2007.00270.x

Ernst \& Young, 2009, Final King III synopsis, viewed n.d., from https://www.saica co.za/Portals/0/Technical/EY\%20Final\%20King\%20III\%20Synopsis.pdf

Gellerman, S.W., 2003, 'Why "good" managers make bad ethical choices', in Harvard Business School Press \& J.L. Badaracco (eds.), Harvard Business Review on Corporate Ethics, n.p., Harvard Business School Publications, Boston.

Hofstede, G., 1983, 'The cultural relativity of organizational practices and theories' Journal of International Business Studies 14(2), 75-89. http://dx.doi.org/10.1057/ palgrave.jibs. 8490867
Hole, G. \& Hawker, S. (eds.), 2004, Oxford English Dictionary, 6th edn., Oxford University Press, Oxford.

Hursthouse, R., 2012, 'Virtue Ethics', The Stanford Encyclopedia of Philosophy, Summer, viewed 15 August 2012 from http://plato.stanford.edu/archives/ sum2012/entries/ethics-virtue/

Institute of Chartered Accountants in England and Wales (ICAEW), 2010a, Exams viewed 03 March 2010, from http://www.icaew.com/index.cfm/route/147361/ icaewga/en/Employers/ACA_qualification/Exams/Exams

Institute of Chartered Accountants in England and Wales (ICAEW), 2010b, Continuing professional development, viewed 03 March 2010, from http://www.icaew.com/ index.cfm/route/159033/icaew_ga/en/Members/CPD/CPD

Institute of Chartered Accountants in England and Wales (ICAEW), 2009, ICAEW Members' handbook: Section 3: Code of ethics, viewed 25 July 2009, from http://www.icaew.com/index.cfm/route/162804/icaew_ga/Members/ http://www.icaew.com/index.cfm/route/162804/icaew_ga/Members/ handbook__2009/pdf

The Association of Accountants and Financial Professionals in Business (IMA), 2009a, Content specification overview, viewed 18 December 2009, from http://www. imanet.org/

The Association of Accountants and Financial Professionals in Business (IMA), 2009b, Continuing education requirements and rules, viewed 18 December 2009, from http://www.imanet.org/

The Association of Accountants and Financial Professionals in Business (IMA), 2005 IMA Statement of ethical professional practice, viewed 14 July 2009, from http:// www.imanet.org/pdfs/statement\%20of\%20Ethics_web.pdf

Institute of Directors in Southern Africa (IDSA), 2009, King Code of Governance for South Africa 2009, Institute of Directors in Southern Africa, South Africa.

Jialiang, H., 2008, 'How are laws practiced? A sociological analysis based on a judicial case in China', Chinese sociology and anthropology 41(2), Winter, 41-77. http:// dx.doi.org/10.2753/CSA0009-4625410202

Kraut, R., 2012, 'Aristotle's Ethics', The Stanford Encyclopedia of Philosophy, Spring, viewed 15 August 2012, from http://plato.stanford.edu/archives/spr2012/ entries/aristotle-ethics/

Livingstone, C. (ed.), 2008, Oxford mini dictionary and thesaurus, Oxford University Press, Oxford.

National Association of State Boards of Accountancy (NASBA), 2010, The uniform CPA examination: Candidate bulletin, viewed 19 February, from http://www.nasba. org/files/2012/07/Candidate_Bulletin.pdf

Nash, L.L., 2003, 'Ethics without the sermon', in Harvard Business School Press \& J.L. Badaracco (eds.), Harvard Business Review on Corporate Ethics, p. 52, Harvard Business School Publications, Boston.

Regis, E. (Jnr), 1980, 'What is ethical egoism?', Ethics 91, October, 50-62. http:// dx.doi.org/10.1086/292202

Richards, D., 2008, The subprime crisis explained, viewed 17 December 2009, from http://www.michaelprittie.ca/pdf/newsletter/october_2008_subprime_crisis_ explained.pdf

Rossouw, G.J., 2002, 'Business ethics and Corporate Governance in the Second King Report: Farsighted or futile', Koers 67(4), 405-419.

South African Institute of Chartered Accountants (SAICA), 2009, Examinations, viewed 18 December 2009, from https://www.saica.co.za/LearnersStudents/ Examinations/tabid/469/language/en-ZA/Default.aspx

South African Institute of Chartered Accountants (SAICA), 2006, Code of professional conduct, viewed 14 July 2009, from https:// www.saica.co.za/documents/Code of_Professional_Conduct_2006.pdf

South African Institute of Chartered Accountants (SAICA), 2008, Continuing professional development (CPD) policy, viewed 18 December 2009, from https://www.saica.co.za/ Portals/0/documents/CPD Policy-\%20with\%20verification\%20November_2008. pdf

Sellers, B.G. \& Arrigo, B.A., 2009, 'Adolescent transfer, developmental maturity, and adjudicative competence: An ethical and justice policy inquiry', The Journal of Criminal Law \& Criminology 99(2), 451-461.

Serratta, H., Bendixen, M. \& Sutherland, M., 2009, 'Core corporate governance dilemmas facing Boards: A South African perspective', South African Journal of Economic and Managements Sciences 12(2), 194-210.

Shao, R., Aquino, K. \& Freeman, D., 2008, 'Beyond moral reasoning: A review of moral identity research and its implications for business ethics', Business Ethics Quarterly 18(4), 513-540. http://dx.doi.org/10.5840/beq200818436

Teske, J.A., 2005, 'A Janus face upon religion from scientific materialism,' Journal of Religion and Science 40(2), 289-297.

Tidmarsh, J., 2009, 'Rethinking adequacy of representation,' Texas Law Review 87(6), 1137-1203.

Van Romburgh, J.D., 2008, 'The training of a forensic accountant in South Africa', MCom mini-dissertation, North-West University, Potchefstroom.

Vranceanu, R, 2005, 'The ethical dimensions of economic choices', Business ethics: A European review 14(2), 94-107. http://dx.doi.org/10.1111/j.1467-8608. 2005.00394.x

Webster's Dictionary and Thesaurus, 2006, Geddes \& Grosset, New Lanark, Scotland, n.p. 